\title{
Research on Influencing Factors of International Student Mobility: An Empirical Study Based on Panel Data
}

\author{
Hua Shen ${ }^{1}$, Peijin $\operatorname{Li}^{1}$ and Yunfeng Luo ${ }^{1, *}$ \\ ${ }^{1}$ School of Public Management, University of Electronic Science and Technology of China, Chengdu 611731, China \\ *Corresponding author. Email: yunfengluo@uestc.edu.cn
}

\begin{abstract}
Based on data from students of 141 countries studying in China, this study used panel data model to explore the socio-economic and educational factors of influence for overseas students, for instance, different educational levels and varying economic developmental levels of countries, to study in China. We found that degree students are more likely to study in China if their home countries have poor higher education, while educational factors in their home countries have little influence on non-degree students. Compared with undergraduates studying abroad in China, graduate students are more attracted to Chinese Government Scholarships and mutual recognition of academic qualifications.

Keywords: international student flow, international students in China, influencing factors, panel data model
\end{abstract}

\section{INTRODUCTION}

In September and October of 2013, China's President Xi Jinping proposed the Silk Road Economic Belt and the 21st-Century Maritime Silk Road, respectively, during his visit to Central and Southeast Asian countries. On March 28, 2015, China's National Development and Reform Commission, Ministry of Foreign Affairs, and Ministry of Commerce jointly issued The Vision and Proposed Actions Outlined on Jointly Building the Silk Road Economic Belt and 21st-Century Maritime Silk Road, also known as The Belt and Road Initiative (BRI). The BRI set up a new avenue to promote political mutual trust, economic integration, and cultural inclusion of all countries and become a community of interests, destiny, and responsibility. In April of 2016, the general office of the CPC Central Committee and the general office of the State Council issued Opinions on the Work of Opening Education in the New Period (WOE), marking a new period for China's educational opening to the outside world, improving its quality and efficiency.

In July of 2016, The Action of Promoting BRI Cooperation on Education (APCE) was launched by the State Council. A supporting document of WOE, APCE put forward the action plan of BRI in the field of education. In APCE, China should take the lead in promoting the development of education, strengthening personnel training, promoting in-depth cooperation, and improving the education level of B\&R countries. APCE also proposed China would provide 10,000 Chinese Government Scholarships to students from these countries every year, promoting studying in China and personnel training as an important part of its educational activities. Additionally, China should pay attention to the coordination of educational policies with
$\mathrm{B} \& \mathrm{R}$ countries and provide suggestions for promoting the exchange of educational policies. The remarkable improvement of higher education continuously enhances China's cultivation of talents. Moreover, with the encouragement of national policies, China's efforts in international education have gradually increased, especially in $\mathrm{B} \& \mathrm{R}$ countries. China constantly improves policies to attract students from around the world.

In 2018, the implementation of the initiative achieved its sixth year. This study analyzes the factors affecting students of different educational and economic development levels to study in China and put forward policy recommendations. It can provide an empirical basis for the Chinese government and other governments to formulate policies regarding study in China and higher education.

\section{LITERATURE REVIEW}

Much of the research on macro-influencers in international student mobility examines the economic, educational, political, and cultural aspects of destination countries. Economic factors specifically encompass economic ties between two countries, including the volume of bilateral trade or global trade and economic accommodation such as GDP or GDP per capita. Educational factors include the ratio of education expenditure to GNP, secondary education enrollment, and support from national institutions.

Tse M. Chen and George A. Barnett (2000) used network analysis from a macro perspective and discovered the volume of global international student mobility is closely related to levels of economic development.[1] Contrary to previous studies, Cheng $\mathrm{Yu}$ and $\mathrm{Hu}$ Huanhuan (2013) utilized multiple linear regression analysis to find that 
economic factors, such as GDP per capita or GDP growth rate, in destination countries do not have a significant influence on international student mobility - rather, the flow of capital, people, and information facilitated by the bilateral trade of goods attracts international students.[2] Moreover, Martin Kahanec (2011) used an econometric approach to find that the quality of higher education in the destination country is the most influential factor.[3]

In addition to economic and educational factors, an analysis of international student mobility between European countries by scholars such as Petr Mariel found the costliness of the destination country, as well as the geographical distance between the two countries, harmed the recruitment of international students. Population size, linguistic and cultural commonality, a warm climate, and global rankings of universities in the destination country are also major influences. However, on the contrary, Yasar Kondakci (2011) argues that geography is not a major consideration for international students in choosing a study destination unless there are other reasons, such as language similarity.[4] Ziguras (2006) suggested the English language, excellent research capabilities, diverse and highquality academic programs, and the size of the opportunity or probability of being able to stay in the destination country become decisive factors in international students' choice of location. [5] Mei Li and Mark Bray (2007) argue that the growth of higher education can attract international students to their own countries; other factors can deter them from studying abroad as well.[6] The factors affecting international student mobility have changed over time. The OECD's Education at a Glance, published between 2010 and 2016, has consistently highlighted the quality of programs at higher education institutions in destination countries, the language used for instruction, the cost of education abroad, and government-related immigration policies as the four main influencing factors, while in the 2017 edition of the Education at a Glance book, interpersonal networks, mobility costs, accreditation of educational standards, and international multilateral agreements were also listed as important determining factors.

From the perspective of historical stage research, there is still a lack of focus on the new era under the BRI. With the development of this initiative, the scale and structure of studying in China has altered. However, there are a few studies on the current situation and countries with different levels of economic development.

In terms of the influencing factors of studying in China, on the one hand, previous studies focused on the world, but rarely involved countries along the BRI route. Most of the related articles are based on simple case and statistical analyses, while a few articles adopt econometric methods that ignore the differences in the number of people leaving the country for higher education, thus affecting their empirical research results. However, the existing research does not compare the influencing factors of countries possessing different educational and economic levels of development.

Specifically, the research questions addressed by this study are: 1) What are the varying factors students of different educational levels consider for studying in China? 2) What are the factorial differences in students from countries with different economic development levels studying in China?

\section{METHODOLOGY}

\subsection{Data}

The data is based on the Concise Statistics of International Students Coming to China (2010-2018), the World Bank, UNESCO, UN Comtrade, the World Bank, the United Nations Educational, Scientific and Cultural Organization (UNESCO), the World Longitude and Latitude Inquiry System, the CEPII Database, and the China Academic Degrees and Graduate Education Information website. Our sample includes 141 countries and covers periods so we have a panel dataset with observations. The sample concludes developed, developing, and the least-developed countries (see Appendix A for country List and classification criterion). Data from these sources have been collated and calculated as needed.

\subsection{Variables}

The dependent variables in this study are the different education level of students coming to study in China, including the number of degree students, non-degree students, undergraduate students, and graduate students. Based on the summary of the different theories, the independent variables are selected as follows.

Gross enrollment ratio, student-teacher ratio, and per capita expenditure as a proportion of GDP per capita reflect the development of higher education in a country and are "push" factors to influence students coming to China. According to the input-output theory, the higher the investment of educational finance, the better the development of the environment, research conditions, and quality of higher education. The student-teacher ratio and per capita financial expenditure as a proportion of GDP per capita are two indicators that mainly reflect its quality in each country. Scholarship opportunities and mutual recognition of higher education qualifications reflect the degree of educational exchange and cooperation, which are the "pull" factors influencing students to study in China.

In selecting the socio-economic indicators, the number of R\&D researchers (per million people), the geographical distance and the total trade between the two countries and whether the country is a developed country are the independent variables. The independent variables are the "push" factors affecting study in China; among them, the number of R\&D researchers (per million people) reflects the level of research and development in a country. Whether a country is developed or not is measured by its GDP per capita, reflecting economic development. The economic factors of a country serve as a basis for the status 
of higher education development, indirectly affecting students' status in China. The geographical distance between the two countries reflects the transportation cost of international students. Meanwhile, countries close to each other often have similar cultural origins and socio-cultural similarities, which are conducive to international students' adaptation to the study environment. The total trade volume between the two countries reflects the economic cooperation between them and influences the number of students studying in China as a "pull" factor.
In building the regression model, the missing value in this dataset is supplemented by the linear interpolation method and linear trend method of adjacent points successively in SPSS. Due to the large variation in the dimension of quantity among the indicators, the indicators were nondimensionalized before being put into the model, using the following formula:

$$
\mathrm{X}^{\prime}=(\mathrm{X}-\mathrm{X} \min ) /(\mathrm{Xmax}-\mathrm{X} \min )
$$

\section{RESULTS AND ANALYSIS}

Table 1. Panel data models of regressions on the number of degree and non-degree students studying in China

\begin{tabular}{|c|c|c|c|c|}
\hline & \multicolumn{2}{|c|}{ Degree students } & \multicolumn{2}{|c|}{ Non-degree students } \\
\hline & $\begin{array}{c}\text { Without } \\
\text { interaction } \\
\text { effects }\end{array}$ & $\begin{array}{c}\text { With } \\
\text { interaction } \\
\text { effects }\end{array}$ & $\begin{array}{l}\text { Without } \\
\text { interaction } \\
\text { effects }\end{array}$ & $\begin{array}{c}\text { With } \\
\text { interaction } \\
\text { effects }\end{array}$ \\
\hline Scholarship opportunities & 0.008 & $0.025 * * *$ & 0.005 & -0.006 \\
\hline Pupil-teacher ratio, tertiary & $0.048 * *$ & $0.044 * *$ & -0.008 & -0.011 \\
\hline Tertiary gross enrollment rate $(\%)$ & $-0.073 * * *$ & $-0.062 * * *$ & 0.001 & 0.008 \\
\hline GDP Government expenditure per students, tertiary (\% of GDP per capita) & 0.002 & 0.006 & 0.004 & 0.007 \\
\hline Mutual recognition of higher education credentials & -0.005 & -0.009 & $-0.006 *$ & $-0.008 * *$ \\
\hline Outbound internationally mobile students numbers & $0.112 * * *$ & $0.11^{* * *}$ & $-0.02 *$ & $-0.018 *$ \\
\hline Total trade between two countries & $0.716^{* * * *}$ & $0.759 * * *$ & $0.751 * * *$ & $0.77 * * *$ \\
\hline Geographical distance between two countries & $-0.075^{* * *}$ & $-0.08 * * *$ & $-0.028 * * *$ & $-0.03 * * *$ \\
\hline Researchers in R\&D (per million people) & 0.026 & 0.021 & $0.065 * * *$ & $0.073 * * *$ \\
\hline GDP per capital & $-0.111 * * *$ & $-0.091 * * *$ & $-0.087 * * *$ & $-0.073 * * *$ \\
\hline Developed $\times$ Scholarship opportunities & - & $-0.108 * * *$ & - & $0.054 * * *$ \\
\hline Developed $\times$ Tertiary expenditure & - & $0.23 * * *$ & - & $-0.142 * * *$ \\
\hline Intercept & 0.041 & 0.024 & 0.01 & 0.009 \\
\hline Adjusted R2 & 0.63 & 0.63 & 0.77 & 0.77 \\
\hline $\begin{array}{l}\text { This section discusses the major influencing factors of } \\
\text { overseas study for degree and non-degree students in } \\
\text { B\&R countries. As with Table } 1 \text {, the research shows } \\
\text { that "scholarship opportunities" are positive at the } 1 \% \\
\text { confidence level. The number of degree students } \\
\text { studying in China increases by } 0.025 \text { units with every } \\
\text { unit increment of scholarship opportunities. The gross } \\
\text { enrollment rate of higher education is negative at the } \\
\text { confidence level of } 1 \% \text {, while the student-teacher ratio is } \\
\text { positive at the confidence level of } 5 \% \text {, indicating that } \\
\text { the lower the quality of higher education in B\&R }\end{array}$ & \multicolumn{4}{|c|}{$\begin{array}{l}\text { The interaction term studies the disparities of the } \\
\text { influencing factors in academic and non-academic study } \\
\text { in China from countries with different economic } \\
\text { development levels. Scholarship opportunities } \\
\text { positively impact international students with academic } \\
\text { degrees from developing countries and those with non- } \\
\text { academic degrees from developed countries. The } \\
\text { financial expenditure per college student in developed } \\
\text { countries has a considerable impact on academic and } \\
\text { non-academic study in China but does not in developing } \\
\text { countries. }\end{array}$} \\
\hline
\end{tabular}
countries, the more students go study in China. In general, education has a significant impact on degree students traveling to China but a small impact on nondegree students.

From the perspective of social economy, the "total trade between two countries" is significantly positive at the $1 \%$ confidence level, while "geographical distance between two countries" and "GDP per capita" is significantly negative at the $1 \%$ confidence level for both degree and non-degree students in China. For nondegree students, the number of R\&D researchers (per 100 students) is significantly positive at the $1 \%$ confidence level, indicating that the more R\&D researchers (per million students) from the source country, the more non-degree students travel to China. 
Table 2. Panel data models of regressions on the number of undergraduate and graduate students studying in China

\begin{tabular}{|c|c|c|c|c|}
\hline & \multicolumn{2}{|c|}{ Undergraduate students } & \multicolumn{2}{|c|}{ Graduate students } \\
\hline & $\begin{array}{c}\text { Without interaction } \\
\text { effects }\end{array}$ & $\begin{array}{l}\text { With interaction } \\
\text { effects }\end{array}$ & $\begin{array}{c}\text { Without interaction } \\
\text { effects }\end{array}$ & $\begin{array}{c}\text { Without interaction } \\
\text { effects }\end{array}$ \\
\hline Scholarship opportunities & 0.001 & 0.008 & $0.024 * * *$ & $0.027 * * *$ \\
\hline Pupil-teacher ratio, tertiary & 0.023 & $0.029 *$ & $0.043 * * *$ & $0.038 * *$ \\
\hline Tertiary gross enrollment rate $(\%)$ & $-0.061 * * *$ & $-0.057 * * *$ & $-0.049 * * *$ & $-0.047 * * *$ \\
\hline $\begin{array}{l}\text { GDP Government expenditure per students, tertiary (\% } \\
\text { of GDP per capita) }\end{array}$ & 0.013 & 0.013 & -0.005 & -0.001 \\
\hline $\begin{array}{l}\text { Mutual recognition of higher education credentials } \\
\text { Socioeconomic Factors }\end{array}$ & $-0.013 * * *$ & $-0.016^{* * * *}$ & $0.008 *$ & $0.007 *$ \\
\hline Total trade between two countries & $0.69 * * *$ & $0.723 * * *$ & $0.276^{* * * *}$ & $0.289 * * *$ \\
\hline Geographical distance between two countries & $-0.055 * * *$ & $-0.06 * * *$ & $-0.049 * * *$ & $-0.05 * * *$ \\
\hline Researchers in R\&D(per million people) & $0.044 * * *$ & 0.035 & -0.014 & -0.001 \\
\hline GDP per capital & $-0.105^{* * *}$ & $-0.095 * * *$ & $-0.046 * * *$ & $-0.036^{* *}$ \\
\hline Developed $\times$ Scholarship opportunities & - & $-0.122 * * *$ & - & $-0.054 * * *$ \\
\hline Developed $\times$ Tertiary expenditure & - & $0.076^{* *}$ & - & 0.035 \\
\hline Intercept & 0.039 & 0.033 & 0.022 & 0.02 \\
\hline Adjusted R2 & 0.66 & 0.67 & 0.43 & 0.43 \\
\hline
\end{tabular}

This section mainly discusses the main influencing factors of undergraduate and graduate study abroad in the countries along the Belt and Road route. From the perspective of education, it is found that the studentteacher ratio of higher education has a significant positive effect on the overseas study of graduate and undergraduate students in China. The scholarship opportunities has a significant positive effect on the study in China, but has no significant effect on undergraduates. Look from the distribution of the scholarship in China, Thurber's award scholarship opportunity than undergraduates, in 2018 , for example, 2018 years of education in China for the total number of 204934 people, including undergraduate students accounted for $63 \%$ of degree was born in China, graduate students accounted for $37 \%$ of degree was born in China, but for postgraduate scholarships to China accounted for $79 \%$ of obtain scholarship education born in China, won a scholarship of undergraduates accounts for only $21 \%$ of academic raw won a scholarship.

Mutual recognition of higher education credentials for graduate students to study in China significantly at the $5 \%$ confidence level is positive, has a significant negative effect on undergraduate students in China, this is mainly due to the academic and non-academic mutual recognition of mutual recognition of countries, the foreign student's structural differences cause nonacademic mutual recognition of national undergraduate in China accounted for measuring the degree of mutual recognition of national accounts for more than. Tertiary gross enrollment rate is significantly negative for undergraduates and postgraduates studying in China at the level of $1 \%$ confidence. The gross enrollment rate of higher education in the country of origin increases by 1 unit, while the gross enrollment rate of undergraduates in China decreases by 0.061 units, and the gross enrollment rate of postgraduates in China decreases by 0.049 units.

From the social and economic dimension, the "trade volume between the two countries" has a significant positive impact on the undergraduate and graduate students in China. Geographical distance between two countries and "GDP per capita" have a significant negative impact on the undergraduate and graduate students in China. "The number of R\&D researchers (per 100)" is significantly positive on the $1 \%$ confidence level for undergraduates in China, indicating that higher emphasis on scientific research and better scientific research conditions in the source countries have a better promoting effect on undergraduates studying in China.

The interaction term is further added to study the differences in the influencing factors of undergraduate and graduate students studying abroad in different economic development countries. Found that the scholarships were more attractive to undergraduate and graduate students from developing countries along the route. Compared with developing countries, the higher the financial input per student of higher education in developed countries, the greater the number of undergraduate students in China, and the impact of the financial expenditure per student of higher education in developed countries on undergraduate students studying in China is more significant.

\section{CONCLUSION}

The empirical analysis of this paper finds some support for The research questions posed in The paper, First, for degree was born in China, students has significant effects of education on The students, students of The higher education of higher learning student/teacher ratio, higher education gross enrollment ratio is lower, The more degree student coming to China to study abroad, and scholarships for education in China was born in China a significant incentive effect. Education factors have less effect on the non-diploma students in China, but for non-diploma students in China's social and economic factors, the volume of trade between the two countries, the number of students of $R \& D$ researchers 
(per one hundred people) have significant positive effects on non-diploma students in China, the geographic distance between the two countries, students per capita GDP has a significant negative effect on nondiploma students in China.

Second, for undergraduate and graduate students studying in China, the scale and quality of higher education in the country of origin has a significant impact on the undergraduate and graduate students studying in China. Compared to undergraduate students, scholarship in China as well as the recognition to the students graduate degree, incentive effect is more apparent, and the students graduate students pay more attention to the factors of higher education student/teacher ratio, shows that compared with lower education level, students are more likely to graduate student degree level because of its low for a high quality of higher education in China to study abroad. The trade volume between the two countries has a significant positive impact on the undergraduate and graduate students coming to China, while the geographical distance between the two countries and the per capita GDP of the source countries have a significant negative impact on the undergraduate and graduate students coming to China. Compared with graduate students, the number of $R \& D$ researchers has a significant positive effect on undergraduate students in China, indicating that higher emphasis on scientific research and better research conditions in the source countries have a better promoting effect on undergraduate students studying in China.

Third, it is found that for the total number of students studying in China, the scholarship in China has a significant positive impact on those with academic qualifications from developing countries and those with non-academic qualifications from developed countries. Scholarships are more attractive to undergraduate and graduate students from developing countries along the route than from developed countries along the route. Fourth, the financial expenditure per student of higher education in developed countries has a significant impact on both academic and non-academic study in China. Compared with developing countries, the higher the financial input per student of higher education in developed countries, the more undergraduate students come to China, and the impact of the financial expenditure per student of higher education in developed countries on undergraduate students' study in China is more significant than that of graduate students.

\section{ACKNOWLEDGMENT}

This research was funded by National Social Science Foundation of China, grant number BFA200072.

\section{REFERENCES}

[1] Tse-Mei Chen, ,and George A. Barnett."Research on international student flows from a macro perspective: A network analysis of 1985, 1989 and 1995." Higher Education 39.4(2000): doi:10.1023/A:1003961327009.

[2] Cheng, Y., Hu, H., and Chen, Q. "International student mobility under the idea of trade gravity model. " Educational Development Research33.19(2013):81-84. doi:10.14121/j.cnki.1008-3855.2013.19.013. (In Chinese)

[3] Kahanec, M. , and R Králiková. "Pulls of International Student Mobility." IZA Discussion Papers (2011).

[4] Yasar Kondakci."Student mobility reviewed: attraction and satisfaction of international students in Turkey." Higher Education 62.5(2011): doi:10.1007/s10734-011-9406-2.

[5] Christopher Ziguras, ,and Siew-Fang Law."Recruiting international students as skilled migrants: the global 'skills race' as viewed from Australia and Malaysia." Globalisation, Societies and Education 4.1(2006): doi:10.1080/14767720600555087.

[6] Mei Li, ,and Mark Bray."Cross-border flows of students for higher education: Push-pull factors and motivations of mainland Chinese students in Hong Kong and Macau." Higher Education 53.6(2007): doi:10.1007/s10734-005-5423-3. 